Susan L. Glosser, Chinese Visions of Family and State, 1915-1953

Berkeley, Los Angeles, London, University of California Press, 2003, 269

p.

\title{
Isabelle Thireau
}

\section{(2) OpenEdition}

\section{Journals}

Édition électronique

URL : http://journals.openedition.org/chinaperspectives/832

DOI : $10.4000 /$ chinaperspectives.832

ISSN : 1996-4617

Éditeur

Centre d'étude français sur la Chine contemporaine

\section{Édition imprimée}

Date de publication : 1 juillet 2004

ISSN : 2070-3449

\section{Référence électronique}

Isabelle Thireau, «Susan L. Glosser, Chinese Visions of Family and State, 1915-1953 », China

Perspectives [En ligne], 54 | July- August 2004, mis en ligne le 25 avril 2007, consulté le 22 septembre 2020. URL : http://journals.openedition.org/chinaperspectives/832 ; DOI : https://doi.org/10.4000/ chinaperspectives.832

Ce document a été généré automatiquement le 22 septembre 2020

(c) All rights reserved 


\title{
Susan L. Glosser, Chinese Visions of Family and State, 1915-1953
}

Berkeley, Los Angeles, London, University of California Press, 2003, 269 p.

\author{
Isabelle Thireau
}

\section{NOTE DE L'ÉDITEUR}

Translated from the French original by Michael Black

1 This study, which follows in the tradition of pioneering works by Elisabeth Croll, Judith Stacey, Kay Ann Johnson and Margery Wolf, deals with the debate about the reform of the Chinese family during the Republican period. Its author, Susan Glosser, gives great importance to one of the elements in this debate: the arguments of reformers in favour of the "small" family, or xiao jiating, in essays and articles published during the course of the first half of the century. She identifies four groups which dominated the discussion: the intellectuals of the movement in favour of a New Culture, the ruling members of the Nationalist government during the Nanking decade, the Shanghai entrepreneurs during the 1930s, and lastly the communist authorities just after they came to power. She then offers a fascinating analysis of the positions taken by their representatives in the public arena.

2 All these reformers agreed in linking China's salvation to the development of the model of the small family, based on freedom of marriage as well as on the greater economic independence of the members of the household. In other words, reform of the family and reform of the state were inseparable; reinforcing individualism would make it possible to assert national power. They did not all, however, establish the same relationship between the three concepts which thus directed the debate: the individual, the nation state and productivity.

3 The radical intellectuals who advocated the emergence of a New Culture demanded greater individual autonomy, in order to work more effectively, once the obstacles 
presented by the existing family system were overcome, towards the common objective: re-establishing the power of the nation. They encouraged individualism not so much as a legitimate value in itself, but rather as a necessary social transformation in the quest to re-establish a strong China.

4 The Nationalist leaders adopted this theme while criticising the family in a more qualified way than the radical intellectuals. While they described the traditional family as a curb on individual development, they did not consider it to be the reason for all the social and political evils encountered, and wanted to preserve the strength and stability of family units which they considered to be an essential mechanism in the formation of the Chinese state.

5 Shanghai entrepreneurs such as You Huaigao saw the small family as the favoured social unit for introducing into China modern values concerning the rational use of time and material resources. The xiao jiating was the favoured site for spreading the principles of economic and social rationalisation, increasing productivity and consumption, and favouring the development of a commercial economy and thus that of the Chinese nation.

6 As soon as they came to power, the communist leaders rejected this entrepreneurial vision for reforming China. However, they did adopt the discourse about freedom of marriage from the New Culture movement, while at the same time drawing inspiration from the Nationalist leaders when they talked of the relationship between the individual and the state: it was a question of reducing family control over the younger generations in order to reinforce the influence of the state over individuals.

7 One cannot recommend reading this book too strongly, which carries out a highly convincing analysis of a considerable body of newspaper articles, reports and essays written by various members of the urban elite during the Nationalist period, and which sheds new light on the links formally established by Chinese intellectuals between reform of the family and reform of the state. 